\title{
Música $^{1}$
}

\author{
Lúcia Barnea* \\ Raanana, Israel \\ luciabarnea@hotmail.com
}

Dizem que o doutor chorou uma vez durante todo o tempo em que esteve doente. Todos tinham terminado de almoçar, os meninos foram ao cinema, e o senhor ficou na mesa com a filha a escutar música.

Eu estava na cozinha lavando meus pratos, com um ouvido na sala de jantar. A filha perguntou se ele estava satisfeito. Depois, se queria ouvir rádio, mas ele preferiu escutar ópera.

Escutei um choro sentido de homem, mas não tive coragem de me aproximar. Fico perturbada de ver homem desmoronar. $\mathrm{O}$ doutor perguntou clarinho:

- Até quando vou poder escutar esta música, meu Deus?

Tudo sucedeu rápido; ele parou logo, pediu para a filha deixá-lo descansar. Coisa estranha de compreender, a cabeça dos homens - o senhor já quase não saía de casa, mal se sentava, sofria de frio no verão, mas se preocupava com a música. A menina me explicou que era Madame Butterfly, uma ópera que o doutor gostava muito.

Quando escutava música, o doutor se concentrava. Esperava na sala os raios de sol; quando batiam forte, deitava-se no sofá que ficava em frente à amendoeira e mandava eu o cobrir com uma colcha leve. Já estava fraquinho, tudo pesava nele. Depois fechava os olhos e pedia para não ser incomodado. Podia passar horas assim. Às vezes adormecia e quando acordava voltava para o quarto. Eu aproveitava para perguntar se ele não queria um suco de fruta, algo para beliscar. Mas ele não tinha fome.

Não era sempre a mesma música. Na hora da faxina eu via os discos fora de lugar. Era tudo nome de gringo, a madame dizia que era música clássica, barroca, romântica. Eu não via nada de romântico naquilo. Gosto é gosto, como bem dizia minha falecida mãe.

A família morava longe, na casa vivia o casal só. Mas agora estava cheia, com todos os netos que vieram para ver o avô.

O doutor sempre foi gente fina, nunca deu trabalho, falava manso, pedia as coisas com educação, mas não dava confiança. No Natal, botava um dinheiro na minha mão e

\footnotetext{
${ }^{1}$ Uma versão deste conto saiu, originalmente, na coletânea Umbrais, publicada pelo Instituto de Cultura Uruguayo-Brasileiro em parceria com a aBrace Editora, em 2009. p. 33-43.

* Antropóloga social e escritora.
} 
dizia que era para comprar uma lembrancinha para minhas meninas. Era médico que operava, mas quando eu comecei a trabalhar já estava aposentado. No início, ele passeava sozinho; depois, passei a acompanhar o doutor para fazer um joguinho na esquina e tomar água de coco. Mas as forças já não davam mais, devagarzinho, ele foi murchando e deixou de sair.

Era homem bonito, mais jovem. Minha patroa tem na sala uma mesa só com fotos dos dois, do casamento, namorando, passeando, já velhinhos - como era posudo, sô! Casar-se com um homem assim dá gosto.

Ele gostava de tomar vinho, de comer creme de abacate com licor de cerejas amargas. Também apreciava muito a minha canjica de milho e a farofa de ovo com alho e salsa picadinha.

O senhor passava muito tempo no quarto e, de vez em quando, eu batia na porta para oferecer um lanchinho e ver se estava tudo bem. Muita gente ligava, mas ele não queria que passasse as chamadas. Era vaidoso, não deixava que ninguém encontrasse ele fraquinho; mas também podia se contaminar com as visitas.

Um dia, perguntei à madame porque os filhos não procuravam no exterior um hospital para tratar o pai. A filha era viajada, passava de país em país com a família por causa da carreira do esposo. Minha patroa respondeu que o marido recebia o melhor que existia no mundo todo. Depois, abriu a bolsa e leu de um papel: “A Medicina é uma mãe generosa, que alarga a existência e promove qualidade de vida. Também se equivoca. Às vezes não dispõe de solução temporal para um problema que surge. Questão de sorte, padecer do mal que a ciência domou".

Parece que a Medicina não sabia o que fazer com a doença do meu patrão. Ele tomava tanto sangue que parecia vampiro, mas logo carecia de mais. Não tinha remédio que ajudasse, era tudo na base do furo na veia. É preciso ter muita fé - o senhor mesmo dizia. Ele gostava de saber que rezavam por ele, falava em energia. Todo dia, às seis da tarde, eu desfiava meu rosário, começando com as ave-marias. Nas missas de domingo eu pedia socorro a São Expedito, o santo das causas impossíveis.

Quando os filhos se foram, a casa ficou muito vazia e o doutor se ressentiu. A madame trabalhava muito, mas todo dia acordava cedo para cozinhar uma comida fresquinha para o patrão. Eu arrumava a casa, lavava e passava. Ficavam ele e eu naquele casarão cheio de móvel antigo e quarto vazio. Quando ela chegava, eu saía.

Uma noite, o doutor caiu no quarto e ninguém soube. Quem avisou foi a vizinha que escutou o pedido de socorro e chamou o porteiro. Desse dia em diante, minha patroa botou acompanhante para ele. Tinha medo de que alguma coisa de ruim pudesse acontecer enquanto estivessem sozinhos. 


\section{Arquivo Maaravi}

Revista Digital de Estudos Judaicos da UFMG

ISSN: 1982-3053

A madame ficava cada vez mais tempo em casa, não tinha ânimo para sair. Eu dormia de vez em quando, sempre que podia. Tenho duas filhas e a rua está cheia de más intenções, não dá para dormir de touca.

O doutor nunca mais caiu. Mas os exames de sangue começaram a piorar. A gente pedia ao laboratório para liberar o resultado do exame bem cedinho. Vinha por fax, o doutor ficava ao lado do aparelho a tarde toda, ninguém podia usar a linha até chegar o que ele esperava. Depois, se fechava no quarto, mas a gente sentia que não era coisa boa. Ele nunca reclamou, mas eu sabia. Arrastava os chinelos, parece que o corpo ficava mais pesado. Eu segurava contra o peito a minha Bíblia e começava a ler. Que mais podia fazer?

Passaram o doutor para o escritório, porque a cama lá era mais alta. O enfermeiro dormia com ele, levava ao banheiro e ajudava com a comida. Minha patroa disse que não tinha sossego com o estranho em casa, mas não podia mais sozinha com o marido. Às vezes, eu chegava de manhã e os olhos dela estavam inchados de tanto chorar e pouco dormir. Ela sentia que estava perdendo o amor da sua vida, com tudo o que ela pelejava para conseguir o sangue e as injeções do tratamento. O patrão acordava muitas vezes durante a noite e a televisão ficava ligada sem parar - eu imaginava o inferno.

Outro dia, a patroa falava com um dos filhos. Disse que estava chegando a hora, que ele e os irmãos tinham que se preparar, que podia ser de um dia para o outro. Depois, ela chamou os outros, um por um, eu me arrepiei toda. E esconjurei.

Duas semanas passaram, e todo dia eles se falavam. Até que um dia a mãe repetiu para os filhos o que o médico tinha mandado dizer, que ninguém tinha bola de cristal, mas que estava próximo.

Todo dia eu entrava para cumprimentar meu patrão; ele perguntava pelos estudos das meninas e dizia para eu prestar atenção com as más companhias. Agora ele apenas sorria, depois nem isso.

Primeiro, chegou a filha mais velha. O pai estava muito cansado, já não tinha assunto para conversar, não saía mais do quarto. $\mathrm{O}$ enfermeiro e a filha banharam o doutor na cama. A menina encheu o quarto com fotos dos filhos e dos netos - disse que era para o pai se sentir acompanhado. O senhor não suportava mais a claridade, e, aos poucos, não abriu mais os olhos. Acho que ele não queria ver o que a filha via. A gente mal percebia que a garota estava em casa, não saía de perto da cama do pai. Molhava sua boca seca, contava histórias divertidas sobre os filhos, sobre o trabalho, dizia que era preciso ser forte - até que o pai mandou parar. De partir o coração.

Não tinha dia que os irmãos não se falassem, às vezes mais de uma vez. Os netos também chamavam. Uma vez, atendi um telefonema do neto maior, que chorava porque também queria vir. Depois, foi a neta que chamou a mãe. $\mathrm{O}$ anjinho estava aflito para tomar o avião porque tinha que entregar dois curativos, um para curar o 
avô e outro para la abuela, que também estava velhinha. Diz que a menina em casa mostrava para o irmão como era para segurar o avô, com as duas mãos, devagarzinho para não cair. Ela carecia de vir e perguntava quem podia tomar o avião com ela.

A vida se transformou num perrengue, o telefone tocava e tocava, muita gente perguntava pela saúde do doutor. Eu entendi que a coisa era séria. A música da Butterfly nunca mais saiu do lugar, o senhor já não queria mais escutar. Eu continuava arrumando outros discos que a filha tocava para o pai.

Na sexta-feira, quando eu cheguei, o doutor já tinha feito o exame de sangue. Entrei no escritório para cumprimentar. Ele estava muito cansado e pedia sangue, mas já não falava coisa com coisa. Minha patroa tinha pavor de ver o esposo naquele estado. Soluçava sem voz, vendo a filha ajoelhada ao lado do pai. Ninguém podia chorar de verdade ao lado do patrão, porque ele não gostava. Eu pedia nas minhas orações para que o sofrimento não durasse muito.

Quando o resultado do exame chegou, deixaram um recado no telefone do chefe do banco de sangue. Ele respondeu duas horas mais tarde, depois que todos já estavam por se desesperar. A filha falou da cozinha para o pai não escutar. O médico explicou que o sangue já não adiantava e que estava na hora de pensar em parar, a mãe já tinha sido avisada. Mas a menina custava a aceitar. O médico dizia que era puro sofrimento, e a filha discutia. Nesta tarde, o hospital mandou avisar que não tinha sangue para o doutor. Falta doador na cidade para tanta carência.

O telefone não parou esta tarde, chamaram da família, os amigos e o médico para contar que tinham se comunicado com outro banco de sangue. No finalzinho da tarde, quando eu já estava pronta para ir, chegaram para colher uma amostra de sangue. Foi um custo, a mocinha espetava a pele, mas estava tudo seco.

Nós duas descemos no mesmo elevador. Ela não sorria nem falava. Eu disse que o doutor merecia tratamento especial, porque era uma boa pessoa. Ela sorriu antes de partir no carro do hospital.

No dia seguinte de manhã, me inteirei que o outro hospital também não tinha sangue para o meu patrão. Que a filha ligou para os irmãos e que eles estavam por chegar. A madame só fazia chorar e não arredava do sofá que ficava do lado de fora do escritório. O homem ainda pedia sangue, mas cada vez se entendia menos. A língua enrolou, ele deixou de falar e se engasgava até para tomar a água embebida no algodão.

Minha patroa preparou suco de laranja, abacate com limão, purê de batata, mas não adiantava, era tarde para o homem. Ele não teimava mais com o enfermeiro porque não queria a fralda, mas mexia a perna para mostrar o incômodo.

Os meninos estavam a caminho. Cada hora ligava um neto para saber do estado de saúde do avô. Os filhos da primogênita me perguntavam quando voltava a mãe. Os meninos também ligaram durante a viagem. Eu atendia os telefonemas para descansar 


\section{Arquivo Maaravi}

a madame e a filha, que estavam muito afobadas. Elas passavam o tempo chorando e lembrando o passado - quando a menina não estava fechada no escritório com o pai. A filha botava o pai ao corrente da viagem dos irmãos e pedia para ele esperar.

Eu não conseguia me afastar daquela casa, saía de noite e voltava cedinho no dia seguinte. A respiração do meu patrão piorava a cada dia. No domingo de tarde, o médico veio para se despedir. E não cobrou. Ele achava que não passava daquela noite. Explicou a situação ao enfermeiro, que depois deixou o escritório. Sentou-se na cadeira do quarto e conversou com a esposa e a filha. Eu me espantei da sinceridade do homem, falando diante do doutor sobre o seu fim. Também conversaram sobre a vida do médico e sobre os planos da minha patroa para o futuro, se ela não achava bom fazer um cruzeiro pelo mar.

Diz que gente rica é outra coisa: quem pode pensar em viajar depois de tanto gasto com o defunto? Que vergonha, falar do senhor assim.

Uma vez escutei na igreja que a Bíblia fala de uma maldição que faz o homem querer de noite que seja dia e de dia que seja noite. Pois aquela casa não parava nem de dia nem de noite, não havia sossego. As últimas horas antes dos meninos chegarem foram muito excitadas. O pai não partiu enquanto os filhos não chegaram, mesmo sem sangue, sem falar, sem comer e com os olhos fechados. A garota não largava o pai, pingava água na boca, massageava as mãos desidratadas, passava creme nas feridas, mexia as pernas e mudava o doutor de posição. De tardezinha, trocamos o lençol depois do banho e perfumamos o doutor. A menina contava as horas que faltavam para a chegada dos irmãos e avisava o pai. Assim a noite passou.

Às 8 horas da manhã tocou a campainha. Estávamos todos meio acordados, meio dormidos. Eram os meninos que chegavam. Beijaram a testa da mãe e voaram para o escritório. Entraram todos juntos, depois cada um ficou a sós com o pai. O que conversaram eu não sei. Depois que o último deixou o quarto, se reuniram no salão principal. O filho advogado leu o que tinha escrito no avião e todos nos emocionamos. Cada filho tinha sua história bonita para contar, um comentário divertido sobre o pai. Todos passavam e abraçavam a mãe. Choveram telefonemas dos netos, dos quatro cantos do mundo. Passou uma hora de choro, de riso e de lembranças.

A filha que chegou primeiro se levantou para servir um café forte aos irmãos cansados da viagem. No caminho, atendeu um chamado. Falou impaciente uns poucos minutos e desligou. Me perguntou de que vizinho eram as crianças que choravam, mas eu não escutava nada. Ela insistia que era um choro suave de bebê, como se estivessem longe.

Eu me arrepiei toda, pensando que os querubins tinham chegado para carregar meu patrão. Saí na carreira atrás da menina, que também pressentia alguma coisa.

O enfermeiro anotava concentrado os sinais vitais do doutor e não percebeu que a respiração tinha empiorado. A menina chamou pelos irmãos e virou o pai de lado para o ar entrar nos pulmões. Chegaram todos ao mesmo tempo e falaram alguma coisa. 
Minha patroa fazia cafuné no cabelo prateado do marido e dizia ao pé do ouvido que amava muito ele; a filha menor, dona de uma voz que o pai sempre admirou, cantou Yesterday, sua música preferida; o filho advogado rezou de mãos dadas com o pai; o caçula agarrou a outra mão e agradeceu o pai; a filha que pediu para o patrão esperar por seus irmãos, liberou o pai do suplício e mandou ele partir em paz.

O doutor chorou uma lágrima, respirou fundo e parou. Aos poucos, os sinais de vida sumiram e o enfermeiro decretou muito tímido que meu patrão tinha morrido. $\mathrm{O}$ médico confirmou.

Três horas mais tarde, a filha menor decidiu que era preciso trocar o pijama do pai para que ele fizesse seu último caminho arrumado, como sempre foi. O corpo estava quase frio, duro mesmo. O que me espantou foi o sorriso no rosto do doutor. Que diferença da expressão sofrida dos últimos meses. Ele estava feliz, distendido, ausente de toda dor e sofrimento dos anos de calvário.

Passado o enterro, cada filho seguiu seu destino e a senhora, devagarzinho, foi acertando o sono da noite. Todo dia algum dos filhos chamava para saber da mãe, mas já não era a louquice de antes.

Durante alguns meses, não se ouviu música naquela casa. Os discos ficaram esquecidos nas prateleiras. A casa era de um silêncio que vexava a gente.

Até que um dia minha patroa pediu para eu levar a vitrola para a sala. Disse que estava com muita saudade do meu patrão e que necessitava ouvir música. Eu levei a Butterfly, e ela se emocionou com o que contei.

Com o meu salário seguinte veio um CD com a música que o doutor não queria deixar de escutar. Na ceia de Páscoa, vou ouvir com as minhas filhas, junto ao que restou desse licor de cerejas amargas.

Feliz quem deixa uma música para ser lembrado.

Recebido em: 10/07/2020.

Aprovado em: 17/07/2020. 